Journal of Advanced Research in Fluid Mechanics and Thermal Sciences

Journal homepage: www.akademiabaru.com/arfmts.html ISSN: 2289-7879

\title{
A Model of Life Cycle on Biogas Feed to Solid Oxide Fuel Cell in Malaysia: Economic and Environmental Perspective
}

\author{
Shafini Mohd Shafie ${ }^{1,}{ }^{*}$, Zakirah Othman $^{1}$, A Harits Nu'man $^{2}$, Nik Nurul Anis Nik Yusuf ${ }^{3}$ \\ School of Technology Management and Logistics, College of Business, 06010, Sintok, Kedah, Malaysia \\ Universitas Islam Bandung, Jalan Tamansari No. 20 Bandung 40116, West Java, Indonesia \\ Department of Energy, Minerals and Materials Technology,Universiti Malaysia Kelantan, 17600 Jeli, Kelantan, Malaysia
}

ARTICLE INFO

\section{Article history:}

Received 22 May 2021

Received in revised form 23 July 2021

Accepted 27 July 2021

Available online 28 August 2021

\section{Keywords:}

Biogas; Solid Oxide Fuel Cell; Life cycle cost; Life cycle assessment

\section{ABSTRACT}

\begin{abstract}
Abundant of palm oil waste creates huge potential in producing biogas. Technically, biogas can be fed as an input gas into the fuel cell system to get the electricity output. This paper aims to estimate the life cycle costs and environmental impact for the biogas feed to the solid oxide fuel cell system in two different models: Individual System and Centralized System. Then the system boundary-setting starts from palm oil plantation until the fuel cell system. The result indicates that the individual system is more efficient due to lower cost and emission compared to the centralized system. Life cycle cost for the individual and centralized system is RM 2.56 / kWh and RM 7.04 / kWh, respectively. Then the carbon dioxide emissions are $0.2034 \mathrm{CO}_{2-\mathrm{EQ}} / \mathrm{kWh}$ and $0.61 \mathrm{CO}_{2}$ EQ / kWh. Hopefully, the outcome from this paper will be able to assist the decisionmaker in planning to model the fuel cell combining with biogas system in the future. Apart from that, its objective is to focus on cost-efficient and more sustainable electricity generation.
\end{abstract}

\section{Introduction}

Nowadays, the world is moving to renewable energy consumption. This is due to the limitation and drawbacks of conventional type of energy resources [1]. Figure 1 shows the percentage of renewable energy consumption per final energy consumption for ASEAN countries. Myanmar is the leading country in this contact, where up to $85 \%$ of energy consumption are from renewable energy. Unfortunately, the pattern showing a decrease. Malaysia's renewable energy consumption only goes up to $5.2 \%$ with the increasing trends. This country is enriched with a vast amount of renewable energy resources such as biomass, solar, small hydro, wind and ocean. These mentioned resources could be the potential alternative fuels as power generation feedstock. Moreover, Malaysia already considered renewable energy as the fifth fuel energy resources as stated in the Fifth Fuel Energy Policy [2]. Sustainable Energy Development Authority Malaysia (SEDA), mention that the

\footnotetext{
* Corresponding author.

E-mail address: shafini@uum.edu.my

https://doi.org/10.37934/arfmts.86.2.126135
} 
improvement of renewable energy project will contribute to total fuel mix that projected to increase [3].

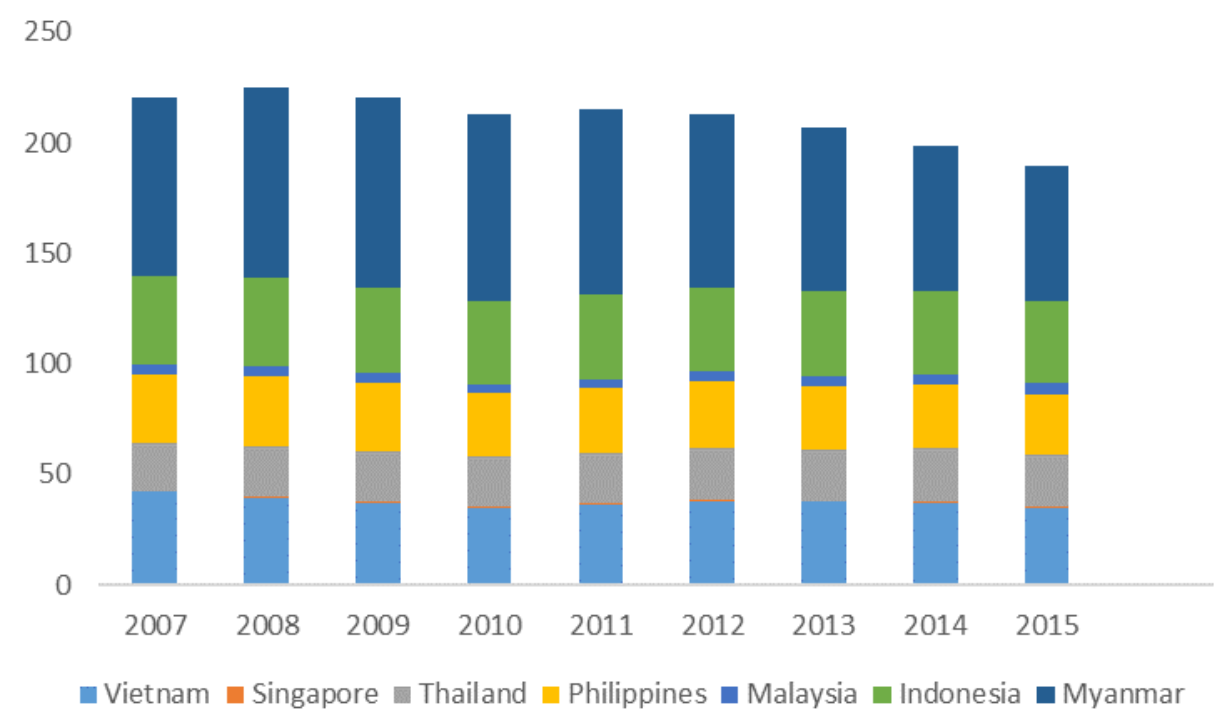

Fig. 1. The percentage of renewable energy consumption in ASEAN countries

The injection of the fuel cell as one renewable energy is still in the early stage in ASEAN countries. The application of fuel cell can provide a million advantages compared to conventional energy resources.

In Malaysia, the government has identified hydrogen fuel cells as crucial research for development since the Eighth Malaysia Plan (2001-2005). From 1997 to 2013, RM40 millions of R\&D funds have been allocated by the Ministry of Science, Technology and Innovation (MOSTI) for the research of hydrogen fuel cells. The targets set for hydrogen energy development in Malaysia are as defined in the Hydrogen Roadmap. In the final phase, hydrogen should be used as fuel for automobiles (using fuel cell), fuel-cell combined heat and power (CHP) and as energy storage [4]. The study under the EU-funded DEMOSOFC project, demonstrated the optimum output of 3 modules with $58 \mathrm{~kW}$ each. They designed it into three main units: (i) the biogas cleaning and compression section, (ii) the three SOFC power modules, and (iii) the heat recovery loop [5]. The article in [6], briefly discussed the advantages and constraints related to integrating the biogas with the solid oxide fuel cells. Feeding biogas toward the solid oxide fuel cell was recognized for cost-effectiveness and technical issues regarding this combination clearly state in this article [7].

Palm oil wastes are potential in producing the biogas. In Malaysia, the utilization of these wastes as energy fuel can be considered too small compared to country's plantation and agricultural yield [8]. Biogas is primarily composed of methane gas and carbon dioxide. It also inclusive of trace amounts of nitrogen, hydrogen, and carbon monoxide. Raw biogas contains $50 \%-65 \%$ biogas $\left(\mathrm{CH}_{4}\right)$, $30 \%-45 \%$ carbon dioxide $\left(\mathrm{CO}_{2}\right)$, hydrogen sulphide $\left(\mathrm{H}_{2} \mathrm{~S}\right)$ and other impurities. The most potential and commercialization of palm oil wastes are using POME in producing biogas.

This paper aims to identify the most critical process of life cycle in terms of environmental and economic toward fuel cell-based electricity generation for two different system design. Figure 2 show the concept apply in this study. 


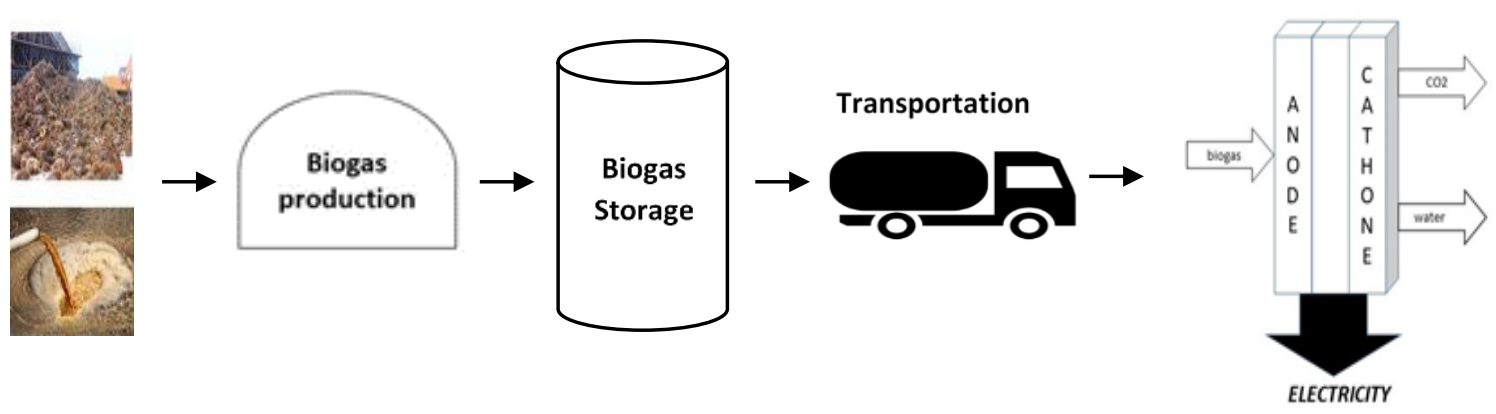

Fig. 2. Concept applied in this study

\section{Methodology}

\subsection{Case Study}

This study considers electricity production using Solid Oxide Fuel Cell (SOFC) fuelled by biogas which is implements in Kedah. Kedah is situated in the northern region of Malaysia with a total area of $9500 \mathrm{~km}^{2}$ of coverage. In 2017, Kedah Oil Palm planted area was reported at 87,538.00 ha which consists of $10 \%$ overall land available in Kedah. Five palm oil mills registered under Malaysia Palm Oil Board (MPOB) [9] will be chosen as a case study in this research. Table 1 list all the Palm Oil Mill in Kedah registered under MPOB. The highest potential of biogas production is at Setia Kawan Kilang Kelapa Sawit Sdn Bhd (E). Hence, in optimising the design whilst considering the minimum cost and its environmental impact, the fuel cell system should be based in this location.

Table 1

Palm oil mills in Kedah registered under MPOB

\begin{tabular}{|c|c|c|c|}
\hline Company & Latitude, Longitude & Biogas Production, $\mathrm{m}^{3}$ & Label \\
\hline Arah Kawasan Sdn Bhd & $\begin{array}{l}5.308823606859161 \\
100.70285936913425\end{array}$ & 98285.94 & A \\
\hline K.K.S Taclico Company Sdn Bhd & $\begin{array}{l}5.520067373237114 \\
100.55668774299988\end{array}$ & 88505.04 & B \\
\hline Kilang Kelapa Sawit Batu Lintang & $\begin{array}{l}5.210964741282499 \\
100.61125011137673\end{array}$ & 88505.04 & C \\
\hline KKS Sungai Dingin & $\begin{array}{l}5.989421384159305 \\
102.11935387868736\end{array}$ & 125909.36 & $\mathrm{D}$ \\
\hline $\begin{array}{l}\text { Setia Kawan Kilang Kelapa Sawit } \\
\text { Sdn Bhd }\end{array}$ & $\begin{array}{l}5.438444637970821 \\
100.6086530322949\end{array}$ & 148847.15 & $\mathrm{E}$ \\
\hline Solid Orient Holdings Sdn Bhd & $\begin{array}{l}5.690455562836122 \\
100.69784585083194\end{array}$ & 134662.46 & $\mathrm{~F}$ \\
\hline
\end{tabular}

Fuel cell-based electricity generation as biogas as input gas was model refers to two conditions, (i) individual and (ii) centralized. In the individual model, each mill (A-F) become the location of fuel cell electricity generation. For the centralized system, Mill $E$ is chosen in locating the fuel cell due to the availability factor. While (A-B-C-D-F) mills will transport their biogas to the system storage then feed into the fuel cell system. The fuel cell system is considered as solid oxide fuel cell that suitable for feeding input biogas. The Eq. (1) until (4) is applied in determining the fuel cell capacity and the electricity output [10].

Life cycle assessment (LCA) is used in order to estimate the environmental impact by applying the Gabi software. All the data for environmental assessment are taken from previous research [10-12]. Figure 3 and Figure 4 were the system boundaries applied in this study. 


\subsection{Individual System}

Figure 3 shows the individual system for fuel cell-based electricity generation. This system starts with Plantation - Biogas Production - Pipeline Transportation - Fuel Cell System. The biogas production estimating $1 \mathrm{~m}^{3}$ of pome will produce 19 to $29 \mathrm{~m}^{3}$ of biogas were referred to the literatures, that stated in the [10-12].

Pipeline transportation is used to feed the biogas to the fuel cell system [13]. The close google map with satellite base map is setting to identify the best location for fuel cell system. It is located based on the nearest and available empty area surrounding each mill [14]. Refer to Figure 3 for the pipeline length for each parameter. Then, Eq. (1) is used to calculate the pipeline transportation cost [15]. Where $C_{T P}$ is the pipeline transportation cost $(R M), P_{P}$ is for the cost of transportation via pipeline $(R M / k m), V_{b}$ is biogas volume $\left(\mathrm{m}^{3}\right)$ and $d$ is the distance to the fuel cell system.

$C_{T P}=P_{P} \times v_{b} \times d$

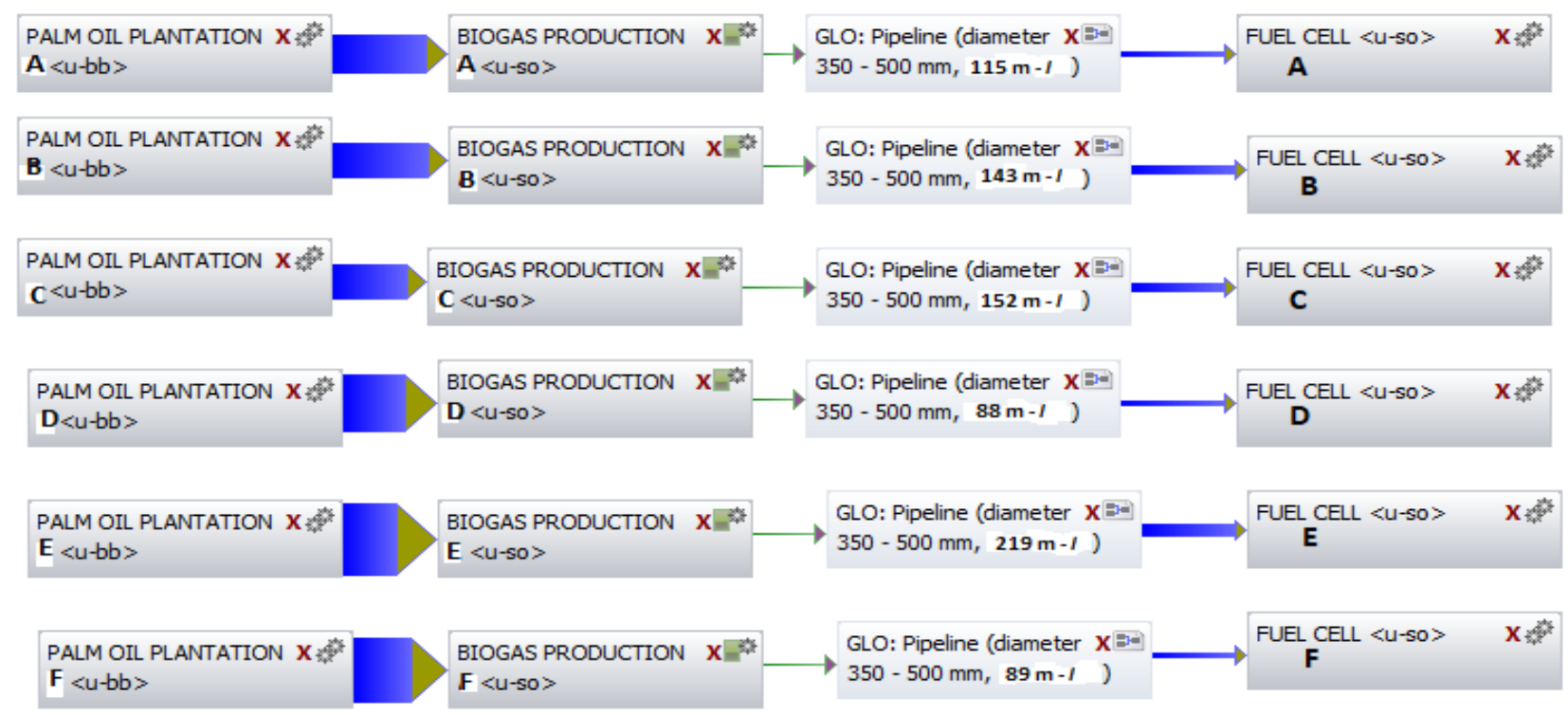

Fig. 3. Individual system for fuel cell based electricity generation

\subsection{Centralized System}

In this system, only one location is chosen for electricity generation. Mill E is set as fuel cell system location. Biogas production in each mill will transport to the Mill E. In this design, there will be biogas storage located at Mill E. In order to transport biogas to the selected mill, the truck with 12.4 tons is selected due to distance of the mill to the centralized fuel cell between $14.2 \mathrm{~km}$ to $36.6 \mathrm{~km}$. Equation 2 is used to calculate the cost for transportation via truck of biogas to the fuel cell system. Where CTT is for truck transportation cost (RM), $P_{T}$ is the cost of transportation via truck $(R M / k m), v_{b}$ is the biogas volume $\left(\mathrm{m}^{3}\right)$ and $\mathrm{d}$ is the distance from biogas production to the biogas storage $(\mathrm{km})$.

$C_{T T}=P_{T} \times v_{b} \times d$

Generally, palm oil mills do not install separate biogas storage tanks. This is due to its high costs [16]. There are various types of biogas storage. For example, double membrane gas storage has advantages like lower implementation cost, long life cycle, ease of installation and much safer [12]. 
Eq. (3) is used to calculate the storage cost. $C_{s}$ is the storage cost (RM) and $v_{b}$ is the biogas volume $\left(\mathrm{m}^{3}\right)$.

$$
C_{S}=-12.918 v_{b}+750004
$$

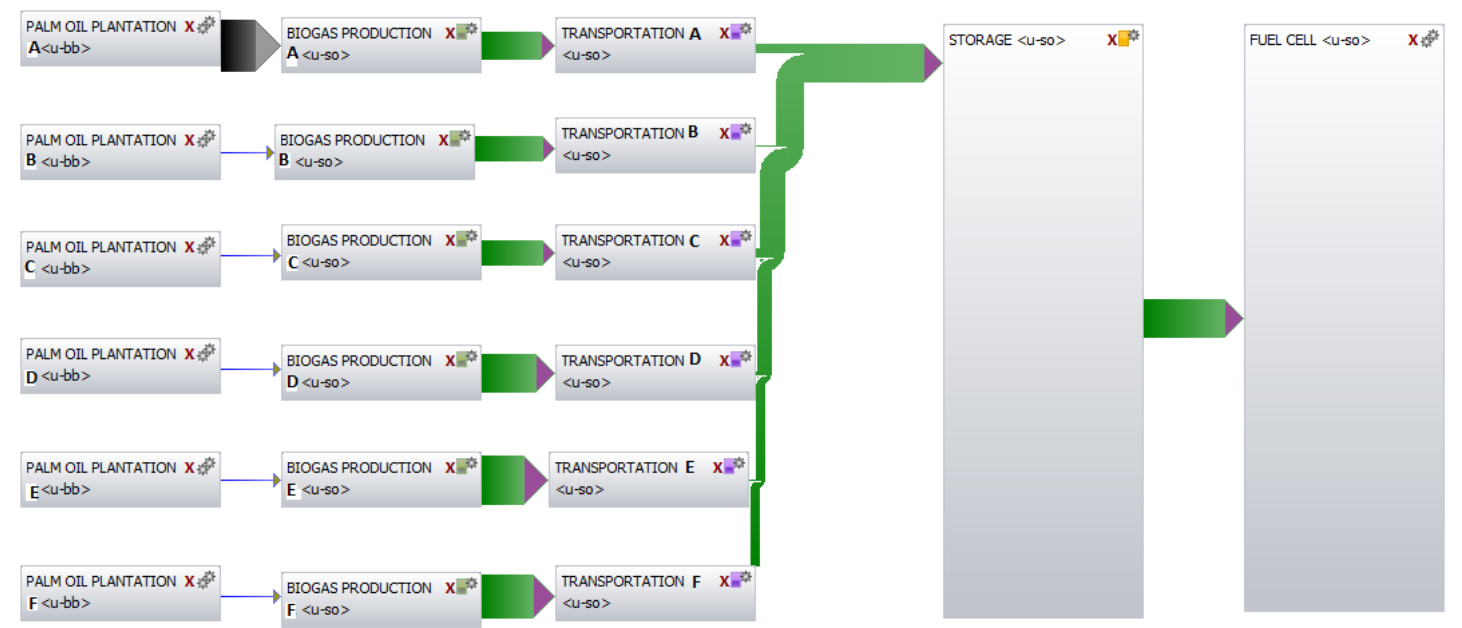

Fig. 4. Centralized system for fuel cell based electricity generation

\section{Results and Discussion}

This section divided into two-part. The first part will discuss the result from both systems applied, (i) individual system and (ii) centralized system. Then the critical process for both systems will be discussed in the next section. Figure 5 shows the comparison result for both, individual and centralized system. The centralized system contributes about $60 \%$ higher in global warming potential compared to the individual system. Based on system boundary setting in Figure 3 and 4, the contribution to global warming is $1.5 \mathrm{~kg} \mathrm{CO}$ 2-EQ / $\mathrm{kWh}$ and $1.86 \mathrm{~kg} \mathrm{CO}_{2-\mathrm{EQ}} / \mathrm{kWh}$. However, the study from [17] with the GHG emission range between $0.2 \mathrm{~kg} \mathrm{CO}$-EO $/ \mathrm{kWh}$ to $0.36 \mathrm{~kg} \mathrm{CO}$ 2-EO/ $/ \mathrm{kWh}$ was due to dissimilar design of system boundary. While the study in [18], contribute about $0.105 \mathrm{~kg} \mathrm{CO}$-EO when reducing the system boundary size that concentrates only at fuel cell system. Based on Figure 5 , indicates that the three-process contributing to global warming are the storage process, transportation process and plantation process. Related to this, it is confirmed that different set of system boundary will affect the overall result of life cycle assessment.

Figure 6 shows the environmental impact toward the LCA of each process in the system boundary. Based on Figure 6, this study shows that proper design for the storage and transportation process are urgently needed in order to reduce the environmental impact. For both individual and centralized system, the contribution toward global warming is $60 \%$ higher with truck transportation compared with pipeline transportation. Obtained that the relationship between $\mathrm{CO}_{2}$-EQ with distance is equal to $4.1 \mathrm{~g} \mathrm{CO}_{2-\mathrm{EQ}} / \mathrm{km}$ via truck transportation. The distances of the mills (A-B-C-D-E-F) to the fuel cell system vary between $14.2 \mathrm{~km}$ to $36.6 \mathrm{~km}$. The study found in [6], indicate that the energy balance can be negative for origin feedstock when the transportation distance is more than $425 \mathrm{~km}$. 


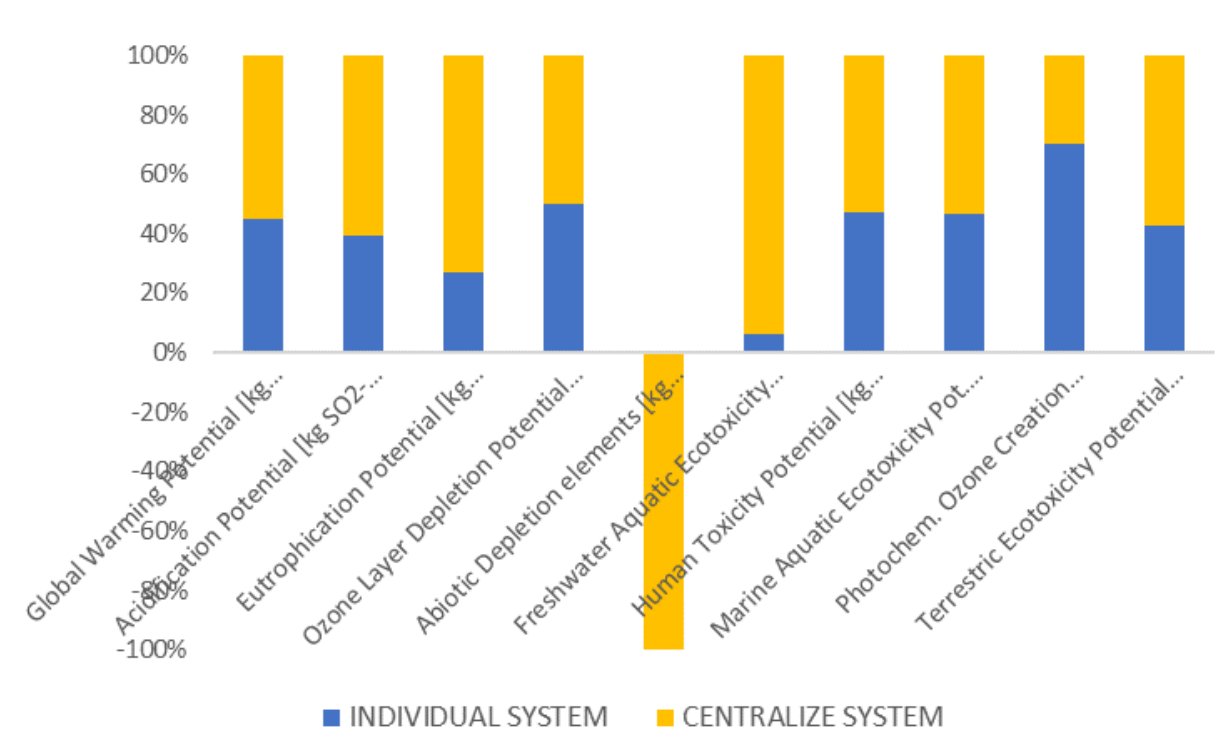

Fig. 5. Comparison results for individual system and centralize system

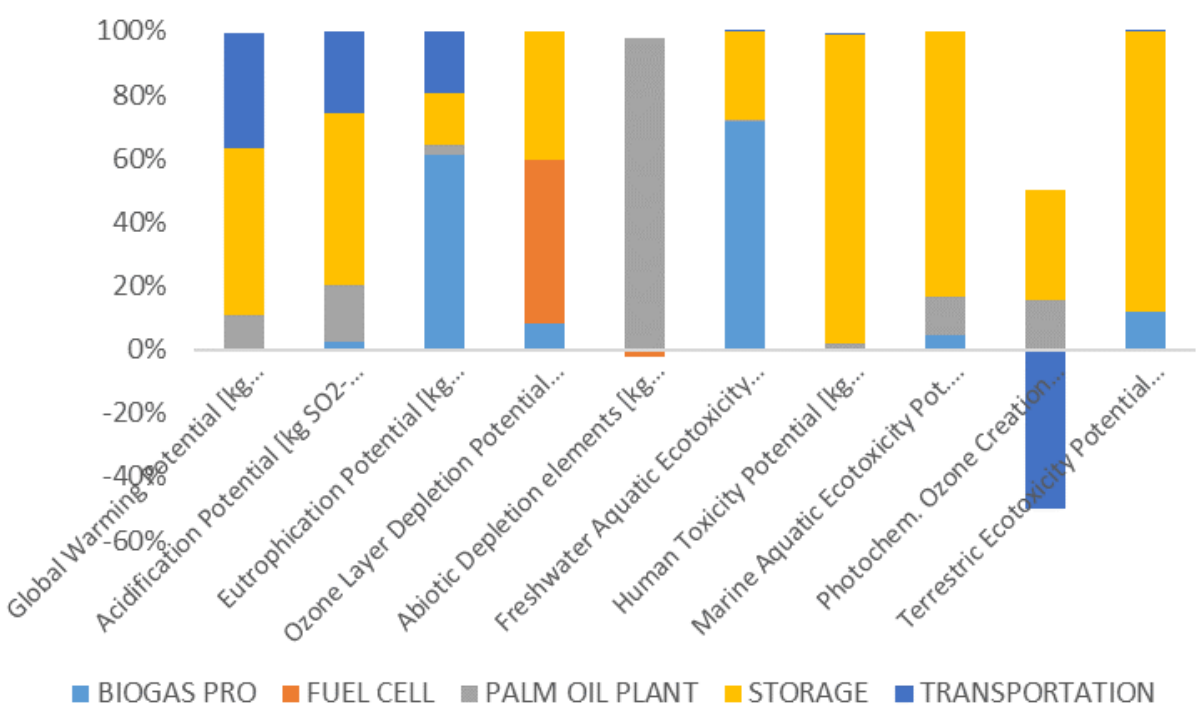

Fig. 6. Environmental impact toward LCA of each process setting in system boundary (Figure 3 )

The relationship between the GHG emissions and electricity generation is where $\mathrm{x}$ is the parameter of electricity generation (Figure 7). According to the previous study, the GHGs emissions are from 200 to $600 \mathrm{~kg} \mathrm{CO}$-EQ [19].

GHG emissions, $y=0.1057 x+1.583$ 


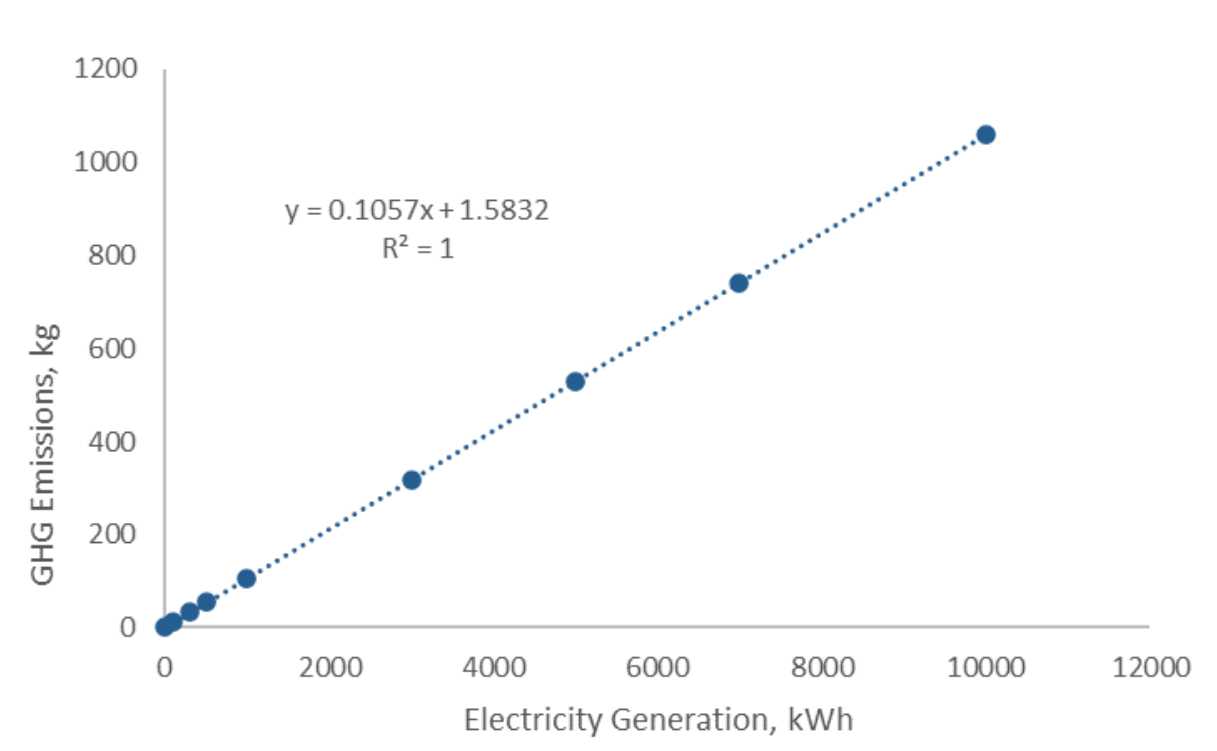

Fig. 7. Relationship between GHG emissions and electricity generation

Figure 8 shows the percentage contribution of climate change per electricity generation for the involved process. Biogas storages show a decreasing pattern when increased electricity generation, $99 \%$ to $54 \%$ of total contribution toward climate change impact. However, the transportation process shows an increasing pattern when increasing the electricity generation from $13 \%$ to $36 \%$ of total $\mathrm{CO}_{2 \mathrm{EQ}}$ emissions. Each km length emits about $0.000041 \mathrm{CO}_{2 \mathrm{EQ}}$ per $\mathrm{kWh}$ electricity generated. Based on the sensitivity analysis, three processes that really contributes toward the GHG emissions are the storage process, transportation process and plantation process. According to [11], the emissions for $\mathrm{NOx}, \mathrm{SO} 2, \mathrm{HCl}, \mathrm{HF}$, and organic compounds are all below detection limits in the exhaust gas. Carbon dioxide emissions for fuel cell is about $110 \mathrm{~kg} / \mathrm{MWh}$ [13].

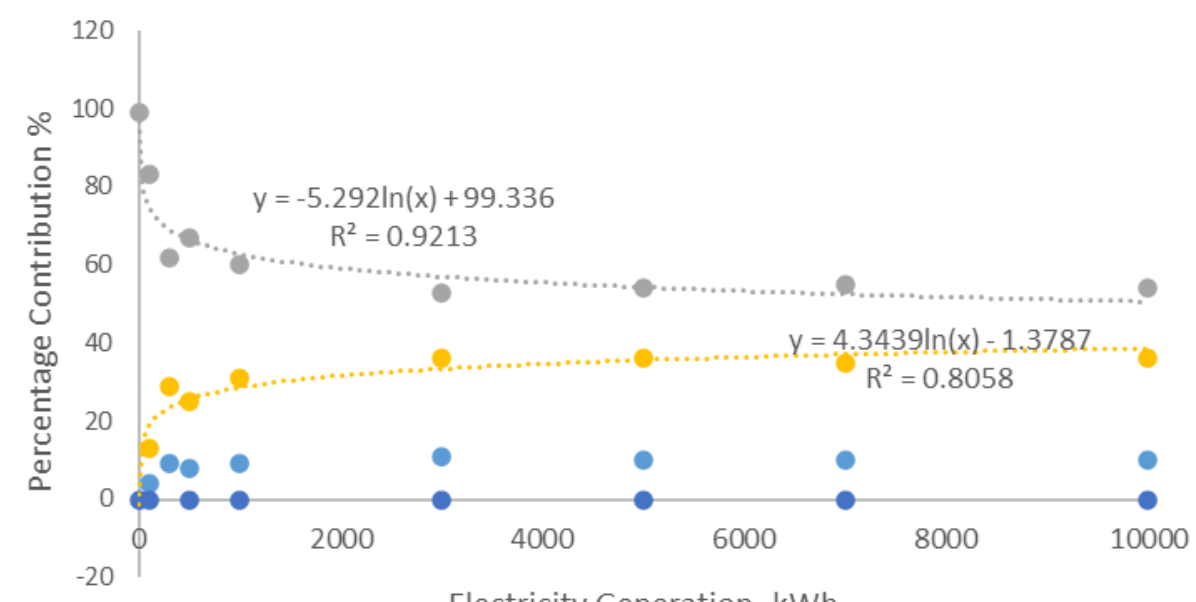

Electricity Generation, kWh

- PALM OIL PLANTATION • BIOGAS PRODUCTION • STORAGE • TRANSPORTATION • FUEL CELL

Fig. 8. Percentage Contribution of climate change per electricity generation

Life cycle cost for both individual and centralized system are RM 2.56 / kWh and RM 7.04 / kWh, respectively. However, the study from Italy found that the life cycle cost for fuel cell is $€ 0.1532 / \mathrm{kWh}$ [20]. According to [21], about $71 \%$ cost reduction is required to enable the fuel cell penetrating the current market. Figure 9 shows the relationship between the cost and carbon dioxide emissions. The 
individual system has lower both in cost and emissions compared with the centralized system. For each mill (A-B-C-D-E-F), it increases from $66 \%$ and up to $83 \%$ for carbon dioxide emission, while for cost, it increases from $63.6 \%$ to $75.9 \%$.

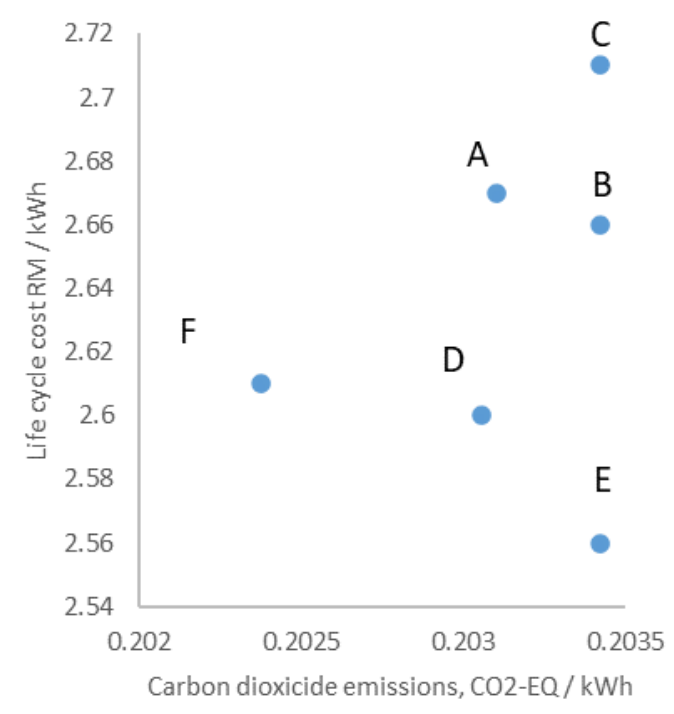

(a)

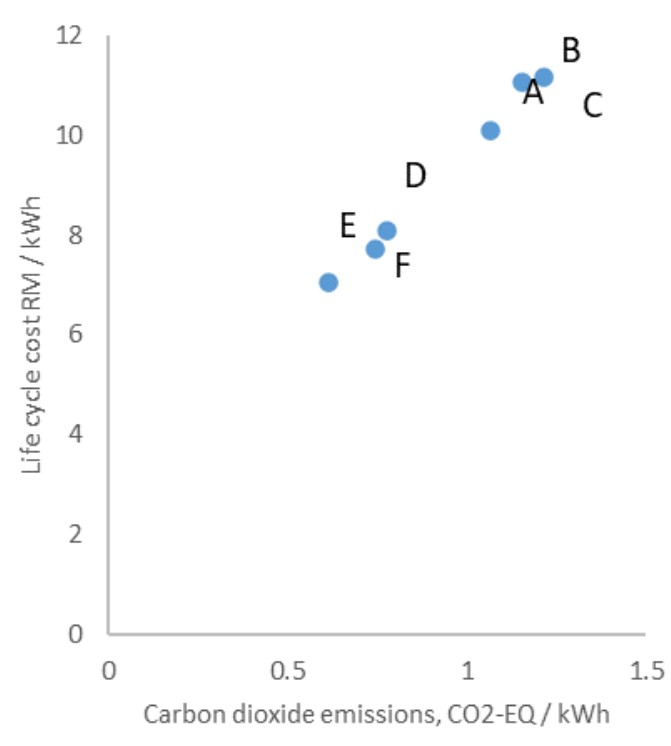

(b)

Fig. 9. Life cycle cost versus carbon dioxide emissions (a) Individual system and (b) Centralize system

\section{Conclusions}

This study aims to identify the most critical process of life cycle in terms of environmental and economic toward fuel cell-based electricity generation. As such, two different system design which consist of (i) individual and (ii) centralized system design has been used.

For the individual system, each mill will be producing fuel cell-based electricity generation that contributes $40 \%$ less carbon dioxide emissions compared with the centralized system. The most critical processes are storage and transportation due to high consumption in cost and its environmental impact. Life cycle cost for both individual and centralized system are RM $2.56 / \mathrm{kWh}$ and RM 7.04 / kWh, respectively. Then the carbon dioxide emissions are $0.2034 \mathrm{CO}_{2-\mathrm{EQ}} / \mathrm{kWh}$ and $0.61 \mathrm{CO}_{2-\mathrm{EQ}} / \mathrm{kWh}$. Hence, individual system design provides the optimum result in term of economic and environment impact.

Considering overall work, these comprehensive studies view critical process that can be used in optimizing opportunities designing the model of fuel cell-based electricity generation which related to economic and environmental perspectives. Adoption of this model requires a serious business model and the firm support by the government is needful.

\section{Acknowledgements}

This research was supported by Ministry of Higher Education (MoHE) of Malaysia through Fundamental Research Grant Scheme (FRGS/1/2018/TK07/UUM/02/3). The authors would like to thank the reviewers and associate editor for their comments that have improved this manuscript. 


\section{References}

[1] Ganapathy, Brintha, Ying Choi Yieng, and Norahim Ibrahim. "Bioelectricity generation based on Acid Red 27 decolourization in microbial fuel cell." Journal of Advanced Research in Applied Sciences and Engineering Technology 5, no. 1 (2016): 42-52.

[2] Samsudin, M. S. N. B. M. M. S. N. B., Md Mizanur Rahman, and Muhamad Azhari Wahid. "Sustainable power generation pathways in Malaysia: Development of long-range scenarios." Journal of Advanced Research in Applied Mechanics 24, no. 1 (2016): 22-38.

[3] Khattak, M. A., A. A. Arifb, A. Hannanc, F. Syukrid, and H. Hamid. "Design and planning of a nuclear power plant in Malaysia: A feasibility report." Journal of Advanced Research in Applied Sciences and Engineering Technology 3, no. 1 (2016): 67-76.

[4] MIDA. Hydrogen: Renewable Power of the Future. 2020 [cited 20201 June 2020]; Available from: https://www.mida.gov.my/home/hydrogen:-renewable-power-of-the-future/posts/.

[5] EPA. How does anaerobic digestion work? 2018 [cited 202017 Jun 2020]; Available from: https://www.epa.gov/agstar/how-does-anaerobic-digestion-work.

[6] Saadabadi, S. Ali, Aditya Thallam Thattai, Liyuan Fan, Ralph EF Lindeboom, Henri Spanjers, and P. V. Aravind. "Solid Oxide Fuel Cells fuelled with biogas: Potential and constraints." Renewable Energy 134 (2019): $194-214$. https://doi.org/10.1016/i.renene.2018.11.028

[7] Abdelkareem, Mohammad Ali, Waqas Hassan Tanveer, Enas Taha Sayed, M. El Haj Assad, Anis Allagui, and S. W. Cha. "On the technical challenges affecting the performance of direct internal reforming biogas solid oxide fuel cells." Renewable and Sustainable Energy Reviews $101 \quad$ (2019): $361-375$. https://doi.org/10.1016/j.rser.2018.10.025

[8] Ismail, H., A. A. Aziz, R. A. Rasih, N. Jenal, Z. Michael, and Azmi Roslan. "Performance of organic Rankine cycle using biomass as source of fuel." Journal of Advanced Research in Applied Sciences and Engineering Technology 4, no. 1 (2016): 29-46.

[9] MPOB. Directory of Malaysian Palm Oil Processing Sector. Malaysian Palm Oil Board, (2019).

[10] Saengprajak, Arnusorn, Aree Katcharoen, Wutthisat Chockua, and Jenjira Piamdee. "Prospective study of application the direct-biogas solid oxide fuel cell system to the biogas plant in Thailand." Energy Procedia 158 (2019): 978-983. https://doi.org/10.1016/j.egypro.2019.01.239

[11] Baldinelli, A., L. Barelli, and G. Bidini. "Upgrading versus reforming: an energy and exergy analysis of two Solid Oxide Fuel Cell-based systems for a convenient biogas-to-electricity conversion." Energy Conversion and Management 138 (2017): 360-374. https://doi.org/10.1016/i.enconman.2017.02.002

[12] Amaco Group Chengdu. Biogas Holder. 2021 [cited 2022129 April 2021]; Available from: http://amococd.com/product/showproduct.php?lang=en\&id=6.

[13] Othman, Muhamad Nazrin, Jeng Shiun Lim, Wai Lip Theo, Haslenda Hashim, and Wai Shin Ho. "Optimisation and targeting of supply-demand of biogas system through gas system cascade analysis (GASCA) framework." Journal of Cleaner Production 146 (2017): 101-115. https://doi.org/10.1016/i.jclepro.2016.06.057

[14] Map Data. 2021 ; Available from: https://www.google.com/maps/d/u/0/edit?mid=1cQeXqpS_3u7uBh7CUVUFaOsCo2TRT7Wv\&II=5.570568625189 226\%2C100.6987433407084\&z=18.

[15] Mohtar, Aminullah, Wai Shin Ho, Ahmad Muzammil Idris, Haslenda Hashim, Jeng Shiun Lim, Peng Yen Liew, Gabriel Ling Hoh Teck, and Chin Siong Ho. "Palm Oil Mill Effluent (POME) biogas techno-economic analysis for utilisation as bio compressed natural gas." Chemical Engineering Transactions 63 (2018): 265-270.

[16] Rahayu, A. Sri, D. Karsiwulan, H. Yuwono, I. Trisnawati, S. Mulyasari, S. Rahardjo, S. Hokermin, V. Paramita, and B. Castermans. "Handbook POME-to-biogas project development in Indonesia." Winrock International 98 (2015).

[17] Rillo, E., M. Gandiglio, A. Lanzini, S. Bobba, M. Santarelli, and G. Blengini. "Life cycle assessment (LCA) of biogas-fed solid oxide fuel cell (SOFC) plant." Energy 126 (2017): 585-602. https://doi.org/10.1016/i.energy.2017.03.041

[18] Nease, Jake, and Thomas A. Adams II. "Comparative life cycle analyses of bulk-scale coal-fueled solid oxide fuel cell power plants." Applied Energy 150 (2015): 161-175. https://doi.org/10.1016/i.apenergy.2015.03.105

[19] Aziz, Md Maniruzzaman A., Khairul Anuar Kassim, Moetaz ElSergany, Syed Anuar, M. Ehsan Jorat, H. Yaacob, Amimul Ahsan, and Monzur A. Imteaz. "Recent advances on palm oil mill effluent (POME) pretreatment and anaerobic reactor for sustainable biogas production." Renewable and Sustainable Energy Reviews 119 (2020): 109603. https://doi.org/10.1016/i.rser.2019.109603

[20] Strazza, Carlo, Adriana Del Borghi, Paola Costamagna, Michela Gallo, Emma Brignole, and Paola Girdinio. "Life Cycle Assessment and Life Cycle Costing of a SOFC system for distributed power generation." Energy Conversion and Management 100 (2015): 64-77. https://doi.org/10.1016/i.enconman.2015.04.068 
[21] Oluleye, Gbemi, Marta Gandiglio, Massimo Santarelli, and Adam Hawkes. "Pathways to commercialisation of biogas fuelled solid oxide fuel cells in European wastewater treatment plants." Applied Energy 282 (2021): 116127. https://doi.org/10.1016/i.apenergy.2020.116127 